\title{
THE ROLE OF LAW IN THE PLANNING PROCESS
}

\author{
Daniel R. MANDElKeR*
}

A lawyer watching the give-and-take of debate over community development and land-use planning policies is struck by the disassociation between the formulation of policy and the way in which it becomes implemented through the legal structure. Policy debates are often unaware that a choice exists in the selection of legal tools, except in the very rough sense that a mutually exclusive option appears to be available between eminent domain and regulatory powers. Even this choice is put too simply as an election between the appropriation of property for public use under eminent domain, following the payment of full compensation, and the regulation of land use under the police power, with no payment of compensation. This article will examine the role of law in the planning process in a broader context, and in doing so will appraise the effectiveness of legal techniques in achieving some of the goals which planners and others have postulated as desirable objectives for an urban society.

In pursuing this inquiry, I will follow a line of thought introduced by Dr. Nathan Glazer. ${ }^{1}$ Dr. Glazer has commented on the character of American "style" in the use and development of our land resources, and has noted how an individualistic bias in that style affects the choice of competing alternatives for the direction of policy. In like manner, I will begin with some observations on the nature of American legal "style" in the resolution of problems dealing with the uses and control of land, and will show how a comparable individualistic bias in the legal process also affects the choice of policy alternatives.

We can begin our discussion with a review of the role of the law in implementing programs for the renewal and rebuilding of our older and larger cities. When implementing the urban renewal objective, the law has made use of both eminent domain and police power techniques. For example, it has dealt with the problem of housing quality through housing codes, adopted locally, which set minimum standards of maintenance and occupancy. This is regulation under the police power. Public acquisition of land for the purpose of eliminating urban blight has also been part of our legal equipment. Especially since 1949 , the federally-aided urban renewal program has encouraged the acquisition, clearance, and rebuilding of blighted areas. Preferred conduct in renewal areas can be induced, however, other than through

*B.A. I947, LL.B. x949, University of Wisconsin; J.S.D. I956, Yale University. Professor of Law, Washington University. Author, Green Belts ANd URBAN Growth: ENGlish Town and Country Planning in Action (I962).

${ }^{I}$ Glazer, "Rebuilding Our Cities," a paper read to the $1962-63$ Washington University faculty seminar on Revitalizing Our Cities. 
regulation and redevelopment. Many states have offered favored treatment in the form of tax abatements for rehabilitated structures and for new structures on cleared redevelopment sites.

More simply, the law has had recourse to the traditional police, eminent domain, and fiscal powers. Of course, the lines between these divisions may blur. Rather than regulate land use through the police power, we can buy from the owner his right to use land in ways harmful to the community, leaving him with title and possession and the right to use his land in any other manner. Punitive taxation might effectively compel the clearance of slum sites. Zoning can substitute for land acquisition by severely restricting land-use alternatives. In one famous case, a parking lot which the owners wanted to redevelop for other uses was zoned as a parking lot so that it would stay that way. ${ }^{2}$

In practice, however, not all of our prescriptions for urban renewal have worked well. We have made relatively little use of tax incentives, and as taxes may often be a marginal cost, the effectiveness of a tax stimulant may be open to question. In addition, tax adjustments present difficult legal problems. Most state constitutions require uniformity of taxation, and amendments would be needed to authorize selective tax treatment. Nor have redevelopment projects succeeded as they should, efforts at wholesale clearance having attracted increasing criticism. As more and more emphasis is placed on the capacity of cities for self-renewal short of wholesale clearance, the role of law as regulator gains increasing importance. In this context, the fate of the parking lot zone is instructive. It was held unconstitutional because it restricted too severely the private use of that site. The point is clear. Law can set the conditions under which private development and redevelopment can occur. But there are limits to these conditions, and these limits must be explored.

The problem can be generalized by referring to the theory of games and to a game which has been called the "Prisoner's Dilemma." Without detailing its nature, I think I can summarize it fairly by saying that, in any deteriorating urban area, it is against the self-interest of any one property owner to rehabilitate his property unless adjacent property owners do so as well. Short of acquisition, how can the law encourage those conditions under which self-renewal will occur by all?

II

An individualistic bias in American legal style inhibits the development of an effective system of legal controls under which the conditions for urban self-renewal can be optimized. 4 Observers have often noted that planning functions best in

\footnotetext{
${ }^{2}$ Vernon Park Realty, Inc. v. City of Mount Vernon, 307 N.Y. 493, I2I N.E.2d 5 I7 (I954) (held unconstitutional).

sor discussion see Davis \& Whinston, The Economics of Urban Renewal, 26 Law \& Contena. Prob. 105 (196r).

'This paper takes its cue from two studies that are relevant to the problems of land-planning law. Professor Willard Hurst, in LAw and the Conditions of FreedoM in The Nineteenth-Century UNited States (1956), explores the "release of energy" principle which guided the development of our natural resources in this century, and which is clearly reflected in our governmental institutions surrounding the
} 
those areas of the community where there is a consensus about community goals. A community consensus is seldom realized in blighted and deteriorating areas, which have a high incidence of transiency, a low incidence of home ownership, and whose inhabitants give environmental concerns a low priority. By way of contrast, consensus about goals is high in suburban areas, where the machinery of zoning is easily adapted to the preservation of the fairly exclusive character of the suburban environment. From this perspective, planning is said to be reactive rather than projective; that is, it reflects the existing image of the community instead of projecting a new and different one. For example, the suburban image is often the sum of a series of choices (about housing and location) that have been made without the help of zoning. A zoning ordinance which zones for half-acre development in a suburban community that has always been built to half-acre densities merely reinforces the sum of these individual choices.

The classic example of a reactive legal concept with a strong individualistic bias is the law of nuisance, which has had a strong influence on the development of zoning. Nuisance law, as it applies to land use, takes care of the case in which harmful acts, done by one landowner on his own land, injure the land of an adjoining landowner. 5 The injured landowner is entitled to sue for an injunction, a court decree that will require the termination of the offending use. Note that the law of nuisance puts the burden of proof on the landowner alleging the objectionable harm. He must bring the action, and must sustain his burden on the proof of nuisance. Note also that the harm, and the cause of action, are personal to him. Unless the harm falls in the public nuisance category, the property owner sues to redress an injury to his own rights in land, and not to redress an injury to the interests of the community. Some absurd consequences may result; some courts have held that a funeral parlor is not a nuisance unless the complaining landowner can see it. ${ }^{6}$ But seen or not, it remains equally injurious (if this is the case) to the area that is affected by its presence.

Historically, furthermore, a nuisance had to be noxious in the physical sense before it was enjoinable. An example of this approach is found in the oft-expressed rule that a violation of the aesthetic is not a sufficient basis for a nuisance action. The point is that a physically noxious use causes obvious detriment to adjoining property, while a nuisance that violates the aesthetic can do so only if it fractures the balance of a neighborhood. In this case the injury is communal rather than private.

There have, of course, been many incursions on the traditional rules. Funeral

control of land use. Professor Allison Dunham, in A Legal and Economic Basis for City Planning, 58 CoLum. L. REv. 650 ( 1958 ), analyzes the role of nuisance and zoning law in preventing property owners from casting on others the external costs arising from the use of land in a manner incompatible with its surroundings. For suggestions about the roles of reactive and projective planning, the writer is indebted to Dr. Alvin W. Gouldner, Professor of Sociology and Anthropology, Washington University.

For a full discussion of the application of nuisance doctrine to the solution of land-use problems, see Beuscher \& Morrison, Judicial Zoning Through Recent Nuisance Cases, 1955 Wis. L. REv. 440.

'E.g., Dawson v. Laufersweiler, 24 I lowa 850,43 N.W.zd 726 (1950). 
parlors in residential districts have often been enjoined, although the aesthetic objection is the only real one that can have any merit in these cases. Most important, the restriction of the nuisance category to physically noxious uses has been dented by a substantial body of case law authorizing injunctions against land uses that are incompatible in the area in which they are located, even though on physical grounds they may not be noxious. By predicating a finding of nuisance on incompatibility of use, these cases permit a good bit of zoning through the judicial process. For example, a funeral parlor in a residential neighborhood will be enjoined on the ground that incompatibility of use creates a nuisance. But the judicial formula is still reactive. The characterization of the funeral parlor as a nuisance depends on the character of the area in which it is located. If the area contains a mixture of residential and commercial uses, the action might not be successful. Neither will a nuisance suit be very effective in deteriorating areas. These areas already contain their quota of mixed and noxious uses, dooming any attempt to prevent further intrusions by judicial decree.

In sum, nuisance law is an ambiguous body of doctrine which provides a method for restraining harmful activities on land. But it defines these harmful activities under a community standard based on the confirmation of existing conditions. Some secondary principles underline this ambiguity. Subjective individual objections to a nuisance are not enough. They must be reasonable individual objections, based on the manner in which an average member of the community would react. Nor are the courts usually projective. They are reluctant, that is, to enjoin a nuisance prior to its construction, on the ground that its impact cannot be determined in advance. But if the property owner waits to bring his injunction until after the nuisance has been established, the court might look to the private nature of his cause of action and hold him estopped from complaining on the ground that he stood by while the nuisance was being constructed.

Nuisance law incorporates an individualistic viewpoint in the regulation of land use which is manifest in related contexts. This discussion has indicated that regulatory controls may condition the environment by setting limits on individual behavior. Thus a zoning ordinance may set limits to building bulk. But it has always been thought that regulatory public measures may not be used to force one type of behavior over another.

A good example of this attitude is the recent Illinois case of People ex rel. Marbro Corporation $v$. Ramsey. In this case the plaintiffs owned a large building in Chicago, built by a famous architect at the turn of the century, and which was an architectural landmark. The owners of the building wanted to wreck and redevelop the property, so they applied to the city for a wrecking permit. They were refused. No official action to acquire the building was pending, but the issuance of the permit was delayed to give the city enough time to find other means of preserving the

${ }^{7} 28$ Ill. App.2d 252, I7I N.E.2d 246 (1960). 
structure. Efforts to interest private foundations failed-an estimated $\$ 3,500,000$ was needed for acquisition and repairs-and after several months the owners of the building brought an action to compel the issuance of a permit. The city admitted that all of the provisions of the ordinance authorizing wrecking permits had been met. With this admission before it, the court ordered the permit to issue:

There is no provision which would give the commissioner the power to withhold an application because of extra-legal considerations.

It is laudable to attempt to preserve a landmark; however, it becomes unconscionable when an unwilling private party is required to bear the expense. ${ }^{8}$

In England, a different legal style prevails. Under authority granted by the Town and Country Planning Act, 1962, the Minister of Housing may list buildings of special architectural and historical interest. Subsequently, unless permission is obtained from the local planning authority, no listed building may be demolished. Nor, without such permission, may a listed building be extended or altered "in any manner which would seriously affect its character."

Clearly, individualistic tendencies in American legal style will influence not only the choice of techniques to implement alternative policies of community development, but the choice of these policies as well. Dr. Glazer discussed three problem areas in the development and redevelopment of our cities in which alternative policies seriously compete for adoption. ${ }^{10}$ Two of these problem areas might be examined, in order to explore in greater depth the legal implications of proceeding in one direction rather than another. One set of problems deals with questions of compaction vs. scatteration in the development of city form, the other with questions of homogeneity vs. heterogeneity in the development of neighborhood areas and in the diversification of building types. These are two issues which have agitated planning circles for some time, and which have a central position in any attempt to work out a theory of community development.

Curiously, the casting of policy solutions in the form of competing alternatives closely resembles the conventional dialectic of the judicial forum, which requires opposing parties to present alternative competing views of the same dispute. But the courts consider the general policy implications of their decisions only as they arise out of the facts of particular cases. We have reversed the usual approach. We have started with competing policy alternatives, and will try to determine the impact on legal structure that would result from the adoption of one competing objective rather than the other.

${ }^{8} 28$ IIl. App.2d at 256 , x7I N.E.2d at 247.

'Town and Country Planning Act, 1962, Io \& II Eliz. 2, c. 38, $\$ 33$ (r)(b). These comments do not mean that the English do not compensate the landowner for excessively burdensome restrictions. See Mandelker, Notes from the English: Compensation in Town and Country Planning, 49 CaLı. L. Rev. 699 (196I).

${ }^{10}$ Glazer, supra note 1. 
III

The Compaction v. Scatteration Argument: Traditional over-abundance of land for development has meant that Americans have put few limitations on the conversion of open space to urban purposes. Until the streetcar revolution of the turn of the century there was little need for concern, as the necessities of movement in the city compelled development at fairly high densities and in successive concentric rings. With the coming of the streetcar, and finally of the automobile, increased mobility permitted development at further and further distances from the city center. The increased mobility which was a consequence of the automobile also removed the necessity for continuous urban development, and encouraged low residential densities. Scatteration resulted. Planners have usually had a preference for urban forms in which development is both nucleated and substantially compacted. This method of development is alleged to possess advantages in urban scale, and is said to reduce the commuting and public costs that scatteration brings. One other byproduct of a compacted pattern is that it should facilitate self-renewal by removing much of the land on the urban fringe from development, thus encouraging the greater use and reuse of available land within existing urban areas.

This familiar history serves to remind us that the founders of modern planning worked against a pattern of development quite different from what we know today. The character of zoning, for example, had been substantially crystallized by rgr6, at which time the effects of the automobile were not fully understood. As a consequence, there was more interest in the problems of high-density development than in the problems of low-density scatter. The need for separating the city into zones assumes that you have disparate uses in close conjunction that need to be separated. Modern residential development on the urban fringe takes place at much lower densities, commercial and industrial uses are gathered into shopping centers and industrial parks, and the result is that exclusively residential districts pre-empt much larger areas. Aided by permissive laws, the suburban home-dweller can incorporate into an independent community, and then use the zoning power to protect his low-density residential preserve. Consequently, zoning by districts can be manipulated to help rather than to hinder the scatteration process.

Furthermore, the zoning movement built very carefully on the existing pattern of nuisance law, which has been seen to be essentially confirmatory of existing conditions. In Euclid v. Village of Ambler, ${ }^{11}$ the United States Supreme Court upheld a zoning ordinance excluding industrial uses from a residential area. The Court relied heavily on the nuisance analogy, and noted the necessity of preventing the intrusion of noxious uses which might spoil a residential neighborhood in a very physical sense. In this perspective, zoning is very much in the American legal style. Once a development decision has been taken, zoning can regulate that decision to ${ }^{11} 272$ U.S. 365 (1926). 
avoid harm to others through the intrusion of disparate uses. To force a develop. ment decision in a certain pattern is another matter.

For a variety of reasons, developers when left with a choice of alternatives have tended to scatter new subdivision projects throughout the fringes of a metropolitan area, and to build at relatively low densities within these subdivisions. From one point of view, scatteration advances the separationist object of zoning, since it removes the residential neighborhood from blighting urban influences. In addition, low-density building enlarges the area of the residential neighborhood, and to this extent decreases its vulnerability from infringement by incompatible uses. Through zoning for large lots and like devices, separate and exclusive suburban zones are then easier to protect. To force compaction rather than scatteration would require a legal technique that would alter prevailing market tendencies, and by forcing development decisions other than those that normally would be taken, would cut across the grain of American legal style.

The point can be illustrated by trying to visualize the kinds of legal techniques that would be needed to implement the open-space plan for St. Louis County, Missouri. ${ }^{12}$ This plan, which follows the pattern of the English green belts, seeks to set aside a large land reserve in the outer reaches of the county which would be restricted from residential development of any kind. The purpose is to prevent the further scatteration of new development.

With imagination, a program of land-use regulation combined with land acquisition can be made available which will be sufficient to implement the open space plan. We have been concentrating on the employment of regulatory powers to achieve land-use objectives. Since a compaction plan runs counter to the development tendencies usually operating in suburban areas, legal difficulties may be encountered in devising regulatory techniques which have the explicit object of implementing a compaction plan. Instead, prohibitions on new development within the restricted area may have to be accomplished through regulations that gain strength from goals and policies not solely related to the control of land use. For this reason, these regulations may support the compaction plan only in an indirect fashion, and they may not be fully effective in carrying it out.

For example, for reasons of health and safety, it would not be too difficult to prevent all substantial development in a flood plain. Controls of this kind would be effective in carrying out the purposes of the open-space plan, at least in floodplain areas. The subdivision ordinance could be drafted to authorize the denial of permits for new subdivisions in those areas of the county where gradients are too steep, or where the absence of public sewer and water connections would create a health hazard. Avoidance of excessive costs in the installation of public facilities would probably justify the prohibition of building on steep slopes, and potential

${ }^{12}$ St. Louis County Planning Commission, Guide for Growth (1962). 
health hazards would probably justify a building prohibition where no public services are available. But the ordinance would defeat the purposes of the green belt to the extent that public services became available throughout the green belt area.

It is also fashionable to control suburban densities by requiring new development to be on large lots of three acres or more. Since the courts can appreciate the suburban aesthetic on which these ordinances are based, they have been fairly easy to support. However, I have noted a Virginia case in which the use of two-acre zoning to preserve a large green belt area was held invalid as an "exclusive" regulation. ${ }^{13}$ Furthermore, to the extent that development occurs even at these low densities the result once more may be to defeat the basic aims of the green belt plan.

Finally, a compaction plan may require so drastic an interference with private development decisions that it may unfairly distribute the burdens and benefits of land-use regulation. If the English experience is any guide, land within the restricted green belt will fall substantially in value, while land without the green belt will rise by a corresponding, if not greater amount. This distribution of benefit and burden can be justified to the extent that it implements a "plan." Nevertheless, in a system in which land is held privately, the incidence of gain and loss will depend on the accident of location based on decisions that were taken at a time when the green belt policy had not been promulgated. While inequalities in the economic impact of land-use regulation do not necessarily foredoom it, fairness nevertheless dictates that we attempt to do equity. I might add that this problem has been very difficult to solve, but that historic experience need not necessarily inhibit continuing attempts to find a workable solution.

In short, existing legal mechanisms are ill-equipped to force the development choices that would be required to carry out a long-range land-use plan based on the compaction principle. In addition, when urban areas grow through the scatteration of new development, legal controls often may not be imposed until private initiative has dictated land use policies, with the result that these controls function primarily to maintain the pattern that has already been established. I do not suggest that the legal structure should not be reorganized and reoriented to accomplish a different set of objectives, but I think we should be quite sure of these objectives before we tackle what may well be a quite formidable task.

The heterogeneity $v$. homogeneity argument: Planners have long assumed that the full implementation of the democratic goal-values implicit in our culture requires the mixing of age levels and of economic and ethnic types within neighborhoods. To a considerable extent, effective neighborhood variety will also require the mixing of building types. While different ethnic groups at the same economic level can occupy structures that are similar in price and style, if age and economic levels are mixed then residential structures must be mixed also. Older persons,

${ }^{13}$ Board of County Supervisors of Fairfax County v. Carper, 200 Va. 653, ro7 S.E.2d 390 (r959). See also Aronson v. Town of Sharon, 295 N.E.2d $34 x$ (Mass. I964). 
for example, would require smaller and easier-to-manage accommodations than families, either in bungalows or in specially-constructed apartments.

Yet the inter-mixing of building types would tend to frustrate rather than to facilitate the process of self-renewal. To return once more to the "Prisoner's Dilemma," we noted that the individual property owner will probably renew his property only if all adjacent owners do so as well. We can then assume that certainty about the future of the neighborhood is one of the prerequisites of an environment in which adjacent property owners would feel confident in their decision to renew. But gray or deteriorating neighborhoods in which renewal is needed are usually areas of mixed use, and in these areas the chances under our present legal structure are not good for preserving the present balance of land use, and for preventing further deterioration. Mixed neighborhoods that we might consciously create would be subject to the same disability.

The point can be stressed by returning to the law of nuisance. We noted that an area that was already mixed in use would, for this reason, be hard to protect under nuisance law from invasion by other harmful uses. The reason was that the courts would likely regard the neighborhood as already committed to a mixed pattern. Similar problems inhere in the administration of zoning ordinances. ${ }^{14}$ Like any regulatory public measure, zoning is subject to the equal protection clauses of state and federal constitutions. In the land-use context, this requirement is strongly protective of individual prerogative, since it requires the like treatment of like uses in like circumstances. As a result, zoning must be uniform within zones. When a residential zone is mixed, and already contains some of the so-called "lower" commercial and multiple-dwelling uses, the exclusion of another lower-order use may be very difficult without violating the equal protection requirement. If deterioration has set in, the result may thus be to accelerate it further, and so a mixed neighborhood will be highly unstable.

For the area as a whole the doctrine of Equal Protection may mean no protection, for any use can demand entry. Selective control to upgrade the area at critical points is destined to failure, for the requirement of like treatment for like uses means that the neighborhood will be judged by its lowest common denominator. A good example of this approach is found in the recent case of City of Tulsa v. Swanson, ${ }^{15}$ which reviewed an ordinance covering a strip commercial area along a busy street. Plaintiffs owned two vacant lots at the end of a commercial strip on one side of the street. Residences adjoined the lots to the east and to the south, but commercial properties, including three filling stations, faced the lots on the other side of the street. In other words, the plaintiffs' lots were critically poised at the edge of a strip of commercial uses. Plaintiffs wanted to erect a filling station. In order to

If An individualistic-reactive bias in zoning administration, of the kind that has been described in this paper, has been detailed in an intensive study of the zoning process in Austin, Texas. SinNey $M$. Willfiela, URBAN ZoNing aNd LAND-Use TheORY (1962).

${ }^{36} 366$ P.2d 629 (Okla. 196I). 
protect the adjoining residences, the city proposed a "buffer zone" for the vacant lots, which would permit only a professional office building not more than one story high, and covering no more than twenty per cent of the lot area. As this structure would be relatively unobtrusive, and would be small in bulk relative to its lot, it would blunt the impact of the commercial area on the adjoining residences.

The court held the buffer zone invalid and allowed the plaintiffs to go ahead with their plans for a gasoline filling station. While the court recognized that a zoning ordinance should be upheld if its reasonableness is fairly debatable, in this instance the ordinance was not in accord with the "physical facts" and had to be struck down. This case simply illustrates how a reactive approach to problems of land use can function in a zoning context. By creating the buffer, the municipality obviously wanted to maintain the existing balance in the neighborhood and to stop the further spread of commercial uses. But the court chose to look at the present character of the neighborhood, and found that the mixture of residential and commercial did not justify any attempt to inhibit the further spread of the commercial area. Its decision to allow the plaintiffs' filling station was also helped by the presence of other filling stations nearby. The court did not see fit to accept the municipality's determination that the future health of the area justified the selective treatment of a critical parcel in a manner different from its neighbors. Note that the limitation on uses in the buffer zone would have forced development into a rather narrow shell, and would have canceled a development decision already made by the owners of the property. In a context in which it was asked to prefer a slightly less offensive commercial use over another, the court refused to make this choice when to do so would effectively have dictated the type of structure that plaintiffs would have had to erect on their property.

The Swanson case is important, for it again illustrates the limitations that landuse controls must face when attempting to interfere positively to control the character of a neighborhood in a selective way. That other courts may be less willing on Equal Protection grounds to interfere with a specific zoning judgment does not hide the fact that the Swanson case represents the traditional view. Even if the court would not capitulate, the municipality, through its council or board of adjustment, quite conceivably would.

In summary, land-use regulations face a good deal of trouble when dealing with unstable neighborhoods in which the certainties of future development are in doubt. The private developer faced with the necessity to undertake self-renewal would not be encouraged that the legal machinery would be able to protect his investment. By the same token, a neighborhood which is built with mixed uses would contain a fair amount of inherent instability from the start, and the continuing protection of neighborhood balance would be hard to achieve. An objection might be made that land could be cleared, sold to a redeveloper, and then built to mixed specifica- 
tions pursuant to a redevelopment plan. But even a redeveloped area must fend for itself after it is redeveloped, and the same objections would apply.

Of course, protective covenants are commonly made applicable to redeveloped tracts, and these provide a private means of enforcement which can prevent the intrusion of an unstabilizing use. For example, protective covenants might preclude the use of any lot in a mixed residential redevelopment area for certain listed (offensive) commercial uses. If a prohibited commercial use threatened to intrude, other property owners subject to the covenants, or better yet a neighborhood association, could seek an injunction to prohibit the intrusion.

But reliance on judicial procedures and on the interposition of the equity jurisdiction will again give a necessarily reactive cast to the proceedings to enforce the protective covenant. The trouble is that equity will enjoin a violation of a protective covenant only if it would not be unfair or unconscionable to do so. To determine whether or not it would be unfair to grant the injunction, equity will look, once more, to the character of the area. For example, if an area that was once exclusively residential has changed over time so that nonresidential uses have intruded, the court may decide that because of "changed conditions" it is no longer equitable to enforce the covenant. Another nonresidential use will then be allowed to intrude, and the process of change will be accelerated. If a neighborhood contains a mixture from the start, even of residential uses, it will be even harder to protect.

Inquiry into the origin of the "changed conditions" that will lead a court of equity to refuse an injunction leads to intriguing speculation. At the beginning, of course, an exclusive residential neighborhood is protected by exclusive residential zoning as well as by exclusive protective covenants. But by the time a "changed conditions" case gets to the court a substantial transformation has occurred, and the neighborhood has usually transmuted into a gray area. At some point, the initial breach has been made, and a careful reading of the cases indicates that it has often occurred with the consent of the zoning authorities. This circumstance simply reflects the instability of zoning in mixed areas, a point that has already been noted,

Of even greater interest is the suggestion in some of the cases that neighborhood change must be brought about through the "acts" of the property owners living in the area. This rationale was expressed in an Illinois case. ${ }^{16}$ Subdivision covenants permitted apartment development only. The land had never been developed, and although a change in building tastes made apartment projects unattractive, the court held that this change was not sufficient to make the original plan inoperable. In short, a court asked to enforce protective covenants also responds after the fact of private initiative. It bases its judgment on the physical condition of the neighborhood, as expressed by the sum total of private development decisions that have been taken to date.

${ }^{10}$ Ockenga v. Alken, 314 Ill. App. 389,4 I N.E.2d $54^{8}$ (1942). 
IV

Comprehensive zoning made a substantial assault on conventional notions surrounding the exercise of the police power. For the first time, the courts sanctioned extensive public controls over the use of land in private ownership. Thirty years later, urban redevelopment and renewal programs forced an equally substantial breach in conventional notions surrounding the exercise of the power of eminent domain. The clearance of slums was recognized as a proper condemnation objective, even though the cleared land was sold back to private redevelopers and was not retained in public ownership. The legal commitment to both programs is now constitutionally secure. A substantial social cost is involved in these commitments, however, as the development of legal institutions was deflected in a manner which may be difficult to alter in view of the inertia of the legal process.

We now appear to be at something of a crossroads. Many are dissatisfied with the comparatively passive role that regulatory legal controls have played in the shaping of the urban environment. They would urge a strengthening of regulatory powers, and more positive intervention in private decisions about building and urban development. Before we can proceed legally in this direction we must first make a series of choices about community and neighborhood form, some of which have been outlined in this paper.

This analysis of the role of the legal process as it affects the implementation of planning objectives has been descriptive rather than prescriptive. I do not mean to suggest that the individualistic bias of our legal system in the area of land-use controls cannot be overcome, nor that tendencies in the other direction do not exist. Nevertheless, I do mean to indicate that any changes in the legal structure that are meant to implement a planning policy must be made with careful consideration of the nature of the legal process, the way in which it has tended to develop, and its capacity for help or for hindrance. The success of any technique will stand or fall depending on the way in which it works with or cuts across the grain of American legal style. Anyone who seeks to utilize law in the planning process must keep this fact in mind. 